\title{
CREATION OF AN OBSERVATION NETWORK FOR ASSESSMENT OF THE IMPACT OF THE PIG COMPLEX ON THE GROUNDWATER AQUIFER
}

\author{
Viktoriia Serdiuk $\boldsymbol{1}^{\natural}$ \\ E-mail:vikasadusad@gmail.com \\ Viktor Maksin \\ ${ }^{1}$ Department of Ecology of Agrosphere and Ecological Control \\ National University of Life and Environmental Sciences of Ukraine \\ 15 Heroiv Oborony str., Kyiv, Ukraine, 03041
}

$\triangle$ Corresponding author

\begin{abstract}
Ukraine, as a party to the Association Agreement, in accordance with Directive 2000/60/EC of the European Parliament and of the Council, recognizes water as the most expensive resource on our planet, which must be protected and saved. Every country and every inhabitant of the planet must do everything possible to reduce the thoughtless use of water and stop water pollution. The priority is the identification of water users and «polluters», as well as the detection and prevention of pollution of water resources, which includes the identification of water sampling points around potential sources of pollution.

The aim of the research is to determine the impact of pig farms on the qualitative and quantitative characteristics of groundwater using existing water intakes to preserve natural water resources from pollution and depletion. An important point for monitoring in this situation is the use of existing water intakes (bores and wells) without additional construction of observation bores and interference in the environment.

To complete the study, it is necessary to create an observation (monitoring) network of selected points and establish the frequency of their study. The observation network should determine the level (static and dynamic) as well as the quality of groundwater, which reflects background concentrations (natural or «conditionally natural»). «Conditionally natural» concentrations may indicate an excess of pollutants, associated with anthropogenic impacts that occurred prior to the activities of a particular entity, in respect of which the study is conducted. Given the changes in the quality characteristics of water, caused by external factors, «conditionally natural» concentrations can be taken as background. The obtained information will allow, depending on the quality and quantity of groundwater (their level) to make management decisions on the management of groundwater resources. Groundwater in rural settlements near enterprises is in most cases the only source of water supply.

The laboratory analysis of water samples from selected points in 2020 showed an excess of color, odor at $60{ }^{\circ} \mathrm{C}$, turbidity, total iron in bores and wells. The detected elevations are due to the peculiarity of the geological structure (aquifer of Eocene sediments). The excess in the hydrogen index is almost 10 times from the surface water body, which can be taken as «conditionally natural» (background) with further study of the specific impact of the complex on the environment. The main indicators that may indicate direct contamination of the pig complex, such as nitrates, nitrites, ammonium nitrogen and microbiological studies, do not exceed the normalized values, set for drinking water. In this case, the specific indicators are within normal limits. Petroleum products were not detected in the studied samples.

Keywords: observation network, groundwater aquifer, groundwater level, groundwater quality, impact on groundwater.
\end{abstract}

DOI: $10.21303 / 2504-5695.2021 .002062$

\section{Introduction}

Water is necessary for the existence of life on the planet. The population is constantly growing, and accordingly the exploitation of natural water bodies is increasing [1]. In addition to meeting drinking and sanitary needs, it is necessary to use water for industrial purposes [2]. One of the powerful water consumers is agriculture [3,4], namely livestock, as it requires annual uniform use of large amounts of water throughout the year [5], as a rule, water supply is provided by groundwater resources. At the same time, animal husbandry can be one of the biggest polluters, the impact of which must be controlled [6].

To control the impact of livestock on water resources, it is necessary to carry out environmental monitoring of groundwater [7]: to determine both qualitative and quantitative indicators. For cattle, the 
average ratio of the formed load above the set pressure level is $16.1 \%$ for cattle, $7.8 \%$ for pigs and $7.1 \%$ for poultry [8]. Regions with pig farms are almost twice less vulnerable to groundwater pollution as cattle, but they are also negatively affected.

Enterprises, namely livestock complexes, in most cases carry out ecological monitoring of groundwater: they control the quality and keep records of water intake from bores and the issue of environmental control is partially regulated, but not always timely and correctly sampled, and studies are chaotically conducted [9]. At the same time, there is a problem that villagers who have bores and wells in their own yards do not always adhere to the sanitary protection zone around the water intake. It is a common phenomenon that at a distance of $10-15 \mathrm{~m}$, and even closer, from the water intake there are latrine pits or cattle are kept, garbage accumulates. The lack of accounting for water intake results in uncontrolled and irrational use. According to surveys, only 2 out of 150 people who consume water from their own bores and wells carry out one-time (seasonal) quality control. It points to the low environmental competency and awareness of both local villagers and the legally unregulated issue of state control of water quality from bores and wells of private households.

Monitoring of water bodies is based on the determination of parameters that indicate pollution, caused by wastewater, animal excrement, storage of waste, manure and synthetic fertilizers [10, 11]. These parameters include: the total number of microorganisms, the total number of coliforms, Escherichia coli (E. coli), enterococci, nitrates, nitrites, ammonium nitrogen [12].

It is most expedient to carry out monitoring according to the established scheme (established water sampling points), which is formed on the basis of hydrogeological maps [13] and with a certain periodicity (enough once a quarter) by linking to seasonality, i.e. by creating an observation network.

The aim of the study is to determine the impact of pig farms on the qualitative and quantitative characteristics of groundwater using a monitoring network to prevent pollution and depletion of natural water resources.

\section{Materials and Methods}

The creation of an observation network for the pig farm was carried out on the example of the Joint Ukrainian-British Limited Liability Company "Niva of Pereyaslavshchyna", a powerful water user (water intake and water use) and a potential polluter. The network is located on the territory of Ukraine (Kyiv region) and consists of 44 sampling points: 32 bores, 10 wells and 2 surface reservoirs, located closest to the complexes No. 10 and No. 11. Bores are located on the territories of complexes and production sites, wells - on the territories the nearest residential buildings, surface water bodies within the settlements. The sampling was carried out within the settlements.

The complex consists of 11 operating pig farms (pig farm No. 12 under construction), of which 10 pig farms have a capacity of 30 thousand heads and 1 pig farm (pig farm No. 11) with a capacity of 50 thousand heads per year. Water supply is due to production bores (accepted as observation). They are located on the territory of the enterprise. Pig complexes No. $1-10$ have 2 bores (operating and reserve), pig complex No. $11-4$ bores ( 2 operating, 2 reserve). There are 2 bores on the tractor crews and 3 bores on the production site. Near the workshop for the production of wall panels, the site (office building, garage-workshop, warehouse) and on the territory of the utility room there is 1 bore. The first pig farm was built in 2005, and since 2008 one pig farm has been built annually. There are no warehouses for storage of plant protection products on the territories of pig farms and production sites. Pesticides and agrochemicals are ordered and imported into the fields as they are applied.

In addition to the sampling and study of water samples from bores, located on the territories of pig farms and production sites, the water sampling was carried out from 10 wells in the territories of the nearest residential buildings and 2 surface reservoirs. The sampling of water from bores was not carried out on the territory of the complex No. 12, as the bore has not been built yet, the complex is under construction, it is planned to build 2 bores (1 operating, 1 reserve).

River water is generally considered safer than pond or well water because it is flowing and has more opportunities for natural biological self-purification. Nitrates can accumulate in well water by leaching manure through the soil or along the manhole of a poorly constructed bore. However, high levels of nitrates in water can come from other nitrogen-containing sources, such as fertilizers. 
Nitrate levels in water can fluctuate greatly in surface waters, but they are usually highest after wet periods and lowest in dry periods [14].

The laboratory analysis of water samples was carried out in accordance with the State sanitary norms and rules "Hygienic requirements for drinking water, intended for human consumption" (SSanRN 2.2.4-171-10) [15].

Indicators of color, odor and turbidity of water are determined in accordance with GOST 3351-74 [16]. Examine the sample to determine the color and odor of water by the organoleptic method. Turbidity of water is determined by the photometric method - by comparing samples of test water with standard suspensions.

The hydrogen index is determined in accordance with DSTU 4077-2001, electrometric method [17].

Calcium and magnesium are determined in accordance with DSTU ISO 11885-2005, by the method of atomic emission spectrometry with inductively coupled plasma [18].

The content of polyphosphates in water is determined in accordance with GOST 18309-72 by the colorimetric method [19].

The content of sulfates in water is determined in accordance with GOST 4389-72 by the complexometric method [20].

The chloride content in water is determined according to GOST 4245-72. Determination of chlorine ion is determined by the method of titration with silver nitrate [21].

The content of ammonia and ammonium ions and nitrites in drinking water is determined in accordance with GOST 4192-82. The sample is examined by determining the mass concentration of ammonia and ammonium ions (total) [22].

The content of nitrate nitrogen in drinking water is determined in accordance with GOST 18826-

73. The sample is examined by the colorimetric method with sodium salicylic acid [23].

The content of total iron in drinking water is determined in accordance with GOST 4011-72. The sample is investigated by measuring the mass concentration of total iron with sulfosalicylic acid [24].

The total stiffness is investigated in accordance with GOST 4151-72. The sample is examined by the complexometric method of determining the total stiffness [25].

The total number of microorganisms (MAFAM) and total coliforms (BCBG) are determined according to MI 10.2.1-113-2005 by the method of fluorescent antibodies [26].

The E. coli content is determined according to MR $10.10 .21-155-2008$ by the method of membrane filtration [27].

The content of enterococci is determined in accordance with the Guidelines for sanitary-microbiological analysis of surface water, approved by the order of the Ministry of Health of the USSR from 19.01.81 N 2285-81, titration method using an alkaline polymyxin medium [28].

\section{Experimental procedures}

According to the selected sampling points, an observation network was formed (Fig. 1, 2). The minimum distance of pig complexes from settlements is $1500 \mathrm{~m}$ for complexes No. $1-10$ and $2870 \mathrm{~m}$ for complex No. 11.

Location of water sampling points:

- No. 1, 2 (2 points) - bores - pig complex No. 1 - $1500 \mathrm{~m}$ from the village of Studenyky, Pereyaslav-Khmelnytsky district;

- No. 3, 4 (2 points) - bores - pig complex No. 2 - $1500 \mathrm{~m}$ from the village of Voznesenske, Zguriv district;

- No. 5-8 (4 points) - bores - pig complexes No. 3, 4-1500 m from the village of Nova Orzhytsia, Zguriv district;

- No. 9-12 (4 points) - bores - pig complexes No. 5, No. 7 - $1500 \mathrm{~m}$ from the village of Paryshkiv, Baryshiv district;

- No. 13, 14 (2 points) - bores - pig complex No. 6 - $1500 \mathrm{~m}$ from the village of Lubomyrivka, Zguriv district;

- No. 15, 16 (2 points) - bores - pig complex No. 8 - 1500 m from the village of Kozliv, Pereyaslav-Khmelnytsky district; 
- No. 17, 18 (2 points) - bores - pig complex No. 9 - $1500 \mathrm{~m}$ from the village of Dvirkivshchyna, Yahotyn district;

- No. 19-26 (8 points), including:

- No. 19, 20 (2 points) - bores - pig complex No. 10 - $1500 \mathrm{~m}$ from the village of Yabluneve, Baryshiv district;

- No. 21 (1 point) - surface water body - Maly Supiy pond, near the village of Gostroluchcha, Baryshiv district;

- No. 22 (1 point) - well - residential area - v. Tuzhiliv, Yahotyn district;

- No. 23, 24 (2 points) - wells - residential area - v. Yabluneve, Baryshiv district;

- No. 25 (1 point) - well - v. Kulyabivka, Yahotyn district;

- No. 26 (1 point) - well - v. Dubove, Baryshiv district;

- No. 27-36 (10 points), including:

- No. 27-30 (4 points) - bores - pig complex No. 11 - $2870 \mathrm{~m}$ from the village of Gostroluchia, Baryshiv district;

- No. 31-33 (3 points) - wells - residential area - the village of Gostroluchcha (northern and central parts), Baryshiv district $-3300 \mathrm{~m}, 3480$ and $4430 \mathrm{~m}$ from the pig complex, respectively;

- No. 34 (1 point) - well - v. Peremoha, Baryshiv district - $3350 \mathrm{~m}$ from the pig complex;

- No. 35 (1 point) - well - v. May Day, Baryshiv district - 4980 m from the pig complex;

- No. 36 (1 point) - surface water body - Trubizh River within the village of May Day, Baryshiv district $-6040 \mathrm{~m}$ from the pig complex.

- No. 37 (1 point) - bore - tractor crew - 900 m from the village Kozliv, Pereyaslav-Khmelnytsky district;

- No. 38 (1 point) - bore - tractor crew - $700 \mathrm{~m}$ from the village Nova Orzhytsia, Zguriv district;

- No. 39 (1 point) - well - workshop for the production of wall panels - Voznesenske village, Zguriv district;

- No. 40-42 (3 points) - bores - production site - Pereyaslavske village, Pereyaslav-Khmelnytsky district;

- No. 43 (1 point) - bore - site (administrative building, garage-workshop, warehouse) - v. Lubomyrivka, Zguriv district;

- No. 44 (1 point) - well - utility room - v. Nova Orzhytsia, Zguriv district.

The sampling of water was carried out by the enterprise, the study of samples was carried out on the basis of the measuring laboratory of quality of drain natural drinking water, of the National University of bioresources and nature management of Ukraine, the study of water samples was carried out on the day of sampling, the samples were not preserved.

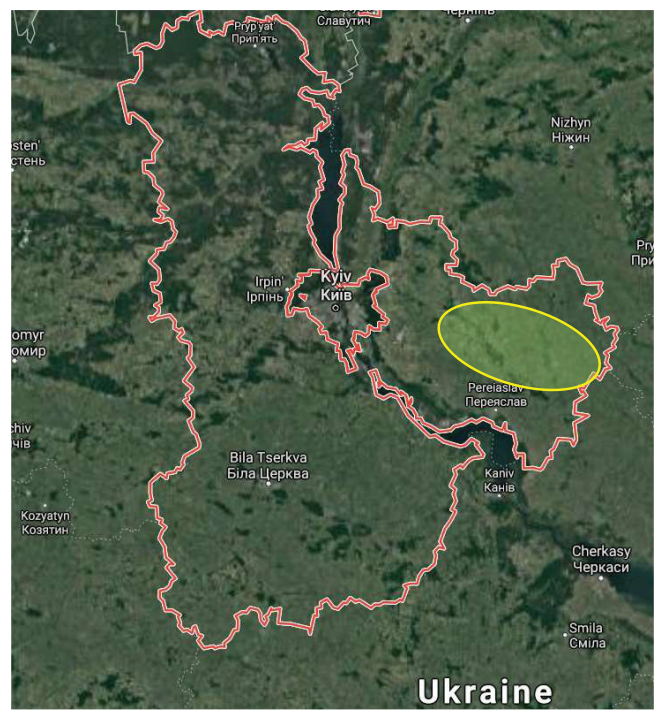

Fig. 1. Radius of observation network location 


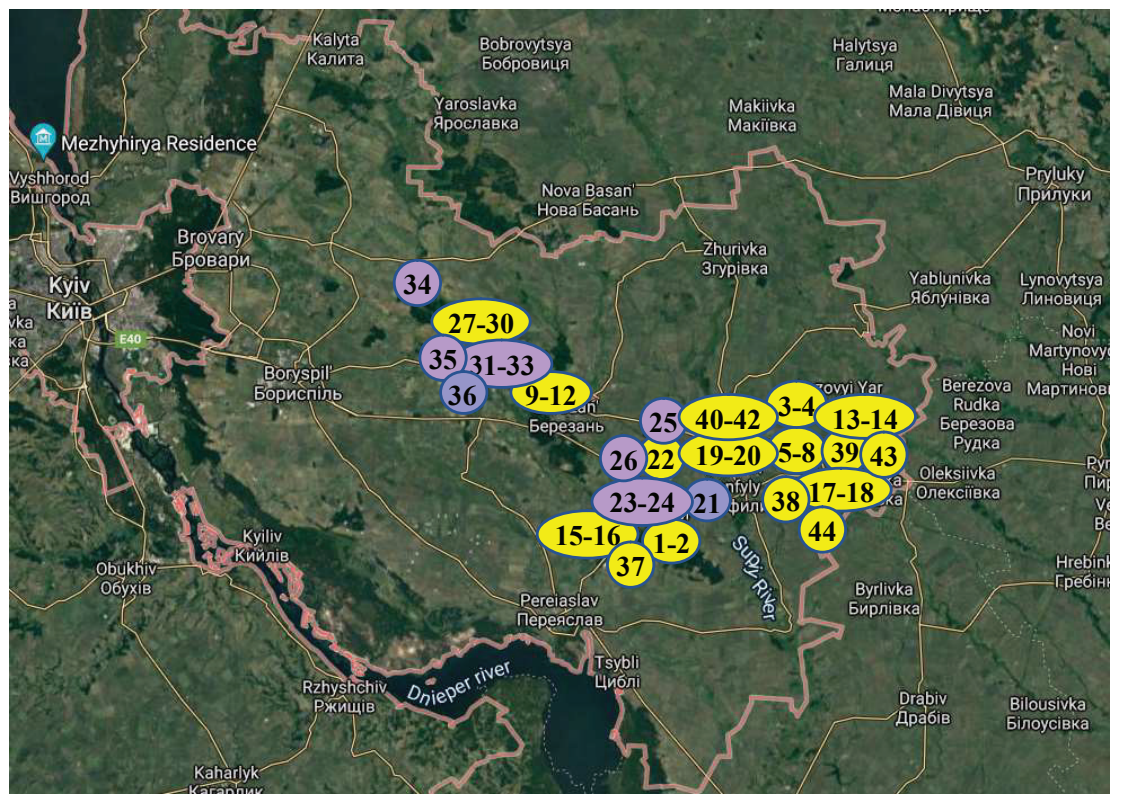

Fig. 2. Location of water sampling points in the observation network, points No. 1-44: bores are highlighted in yellow, wells in purple, and surface water bodies in blue

\section{Results and discussion}

The sampling and testing of water from bores were carried out quarterly with reference to seasonality: I quarter - March 2020, II quarter - June 2020, III quarter - September 2020, IV quarter - December 2020 (Fig. 3-6).

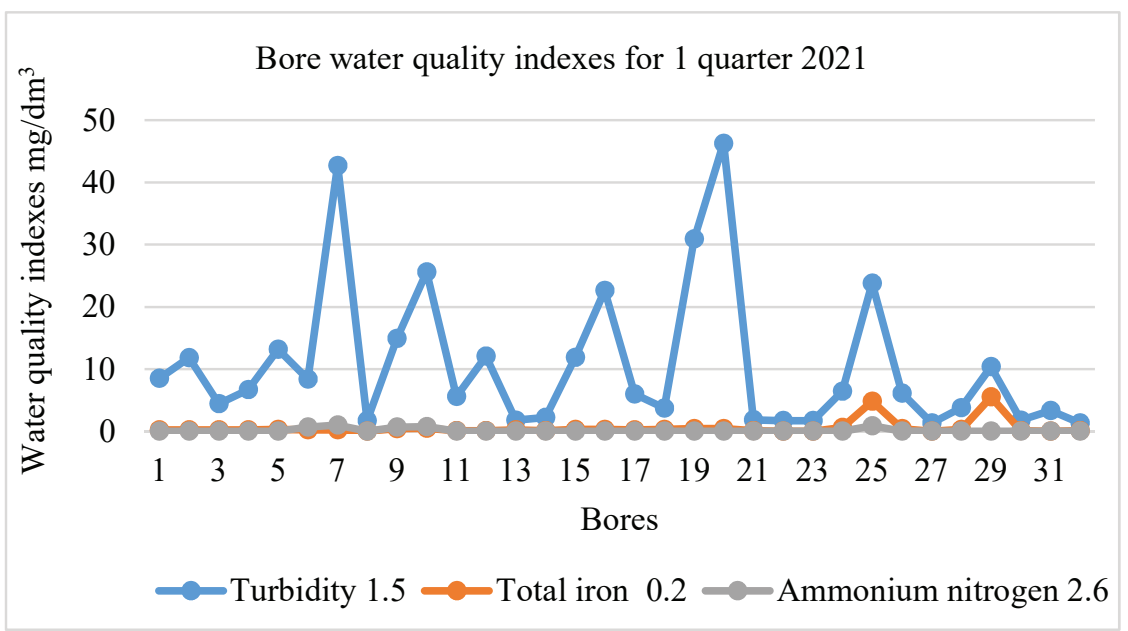

Fig. 3. Water quality from bores in the first quarter of 2020

As can be seen (Fig. 3), the largest excess was:

- turbidity $-46.3 \mathrm{mg} / \mathrm{dm}^{3}$ (31 times) in the bore No. 20, pig complex No. 10. Other excesses averaged 7.2 times;

- total iron $-5.5 \mathrm{mg} / \mathrm{dm}^{3}$ (27.5 times) in the bore No. 29 at the tractor crew. The average excess was 2 times;

- ammonium nitrogen - no excesses.

As can be seen (Fig. 4), the largest excess was:

- turbidity $-66.0 \mathrm{mg} / \mathrm{dm}^{3}$ (44 times) in the bore No. 15, pig complex No. 8. Other excesses averaged 9 times; 
- total iron $-2.2 \mathrm{mg} / \mathrm{dm}^{3}$ (11 times) in the bore No. 9, pig complex No. 5. The average excess was 0.5 times;

- ammonium nitrogen - no excesses.

As can be seen (Fig. 5), the largest excess was:

- turbidity $-13.5 \mathrm{mg} / \mathrm{dm}^{3}$ (9 times) in the bore No. 9, pig complex No. 5. Other excesses averaged 3 times;

- total iron - $1.4 \mathrm{mg} / \mathrm{dm}^{3}$ (7 times) in the bore No. 9, pig complex No. 5. On average, the excess was 2 times;

- ammonium nitrogen - no excesses.

As can be seen (Fig. 6), the largest excess was:

- turbidity $-15.0 \mathrm{mg} / \mathrm{dm}^{3}$ (10 times) in the bore No. 32 on the territory of the utility room. Other excesses averaged 2 times;

- total iron $-2.8 \mathrm{mg} / \mathrm{dm}^{3}$ (14 times) in the bore No. 24, pig complex No. 11. On average, the excess was 1.5 times;

- ammonium nitrogen $-4.9 \mathrm{mg} / \mathrm{dm}^{3}$ (1.9 times) in the bore No. 8 , complex No. 4 . The average excess was 1.2 times.

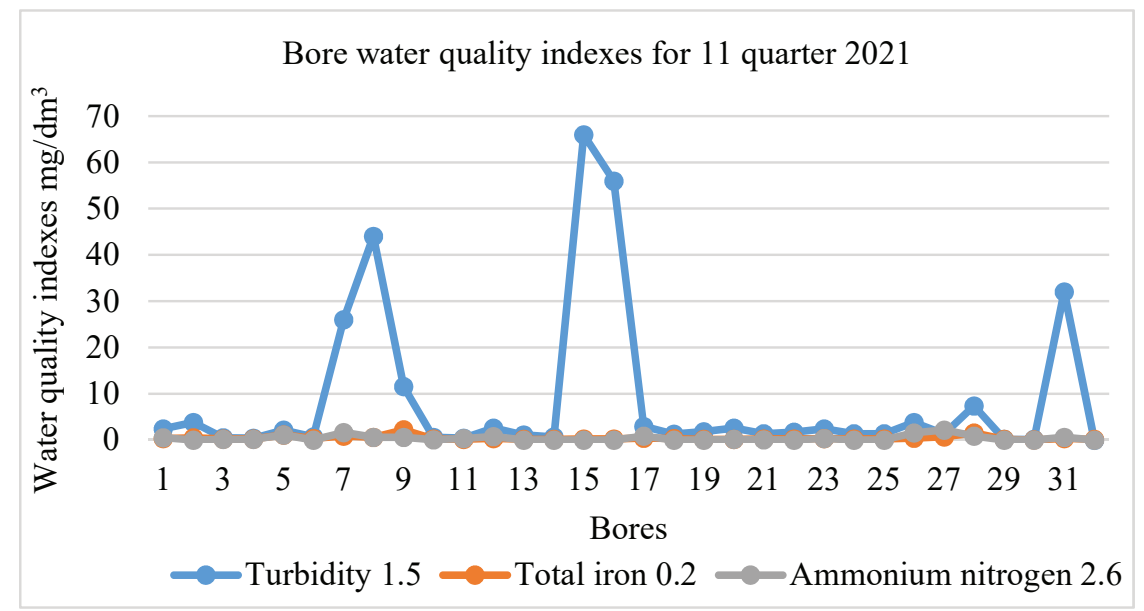

Fig. 4. Water quality from bores in the second quarter of 2020

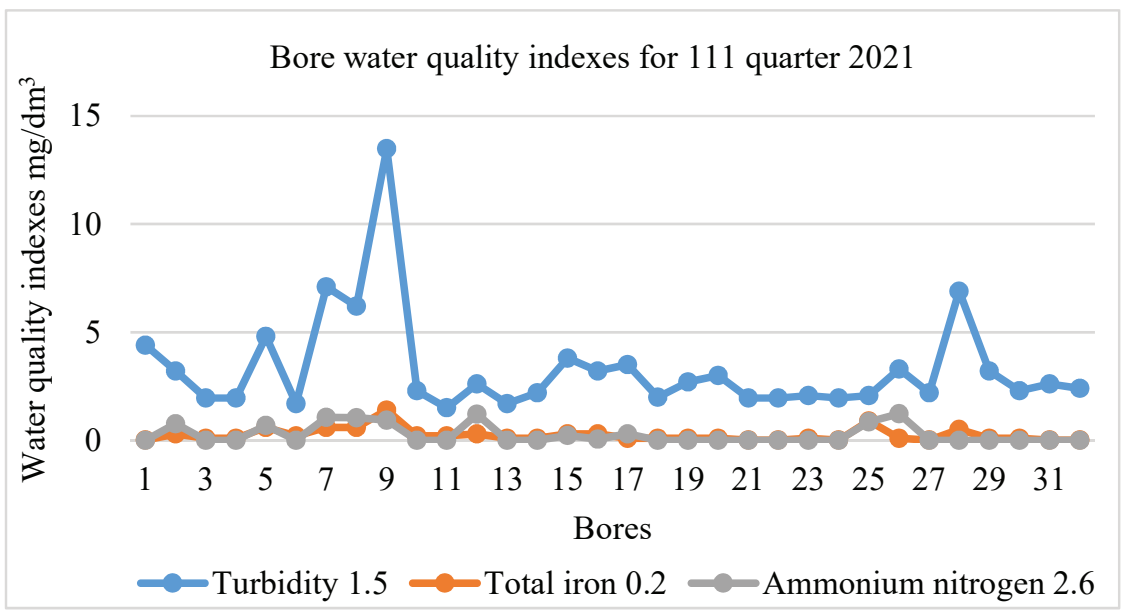

Fig. 5. Water quality from bores in the third quarter of 2020

Seasonal changes in water quality in 32 bores were analyzed for physicochemical parameters in Fig. 3-6 according to the established concentrations and by means of point estimation, 
at which indicators, on which deviations from the established norm were revealed, were taken. Deviations were on indicators: turbidity, total iron, ammonium nitrogen (ammonium), including organoleptic - color and odor at $60^{\circ} \mathrm{C}$.

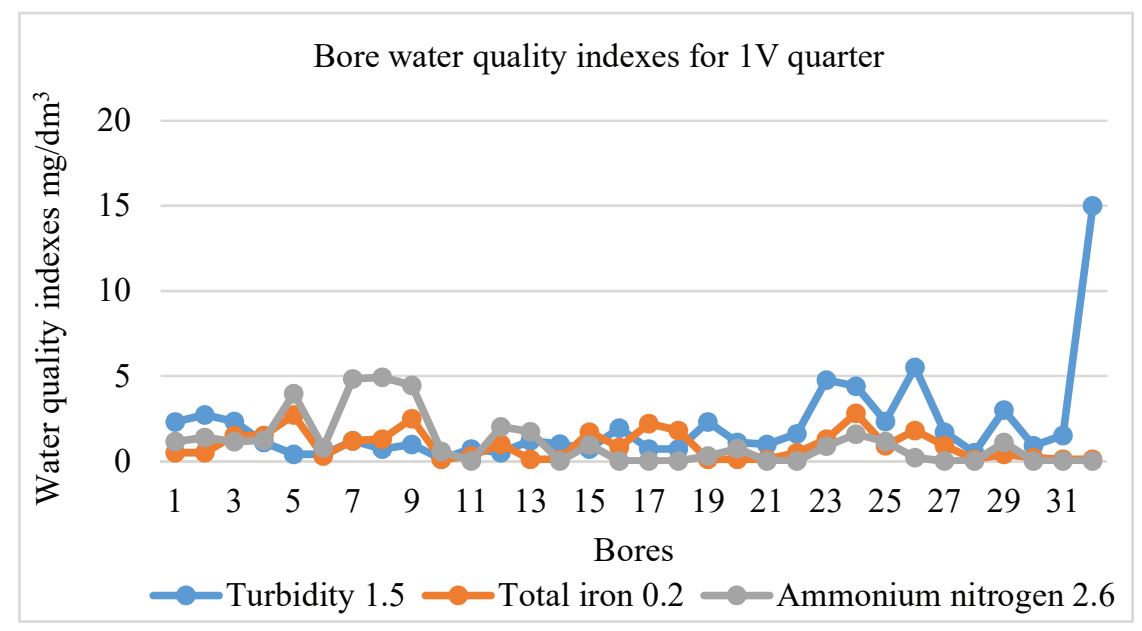

Fig. 6. Water quality from bores in the fourth quarter of 2020

It was determined, that $101-160$ points (40\%) - the largest deviation from the established standards, $51-100$ points $(30 \%)$ - the average deviation, $1-50$ points $(30 \%)$ - moderate deviation, 0 points - no deviation.

The calculation of the score was carried out according to mathematical data, the maximum scores for deviations were determined: 32 bores 5 indicators with detected excesses $=160$ points the maximum deviation, 0 points - no deviations. Each deviation of the indicator from the norm for each sampling point is counted as 1 point.

Weather conditions of Kyiv region in 2020:

- I quarter was warm and with a small amount of precipitation, with an average daily temperature of $+3.6^{\circ} \mathrm{C}$ and an average rainfall of $28.1 \mathrm{~mm}$;

- II quarter - average temperature $+14.2^{\circ} \mathrm{C}$, average precipitation $-76.2 \mathrm{~mm}$;

- III quarter - average temperature $+20.6^{\circ} \mathrm{C}$, average precipitation $-27.4 \mathrm{~mm}$;

- IV quarter - average temperature $+6.3^{\circ} \mathrm{C}$, average precipitation $-31.4 \mathrm{~mm}$.

Summarizing the data, obtained on bores for the first quarter, we found a point deviation in terms of color -32 points, odor at $60{ }^{\circ} \mathrm{C}-19$ points, turbidity -30 points, total iron -16 points, ammonium nitrogen (ammonium) - 0 points. In total -97 points (average). During the second quarter, the point deviation was -43 points (moderate): color -6 points, odor at $60{ }^{\circ} \mathrm{C}-2$ points, turbidity -17 points, total iron -18 points, ammonium nitrogen (ammonium) -0 points. For the third quarter -63 points (average): color -14 points, odor at $60{ }^{\circ} \mathrm{C}-6$ points, turbidity -31 points, total iron -12 points, ammonium nitrogen (ammonium) - 0 points. For the IV quarter -61 points (average): color -18 points, odor at $60{ }^{\circ} \mathrm{C}-4$ points, turbidity -13 points, total iron -22 points, ammonium nitrogen (ammonium) -4 points. The best quality water in terms of points was in the second quarter.

In 2020, according to calculations, the maximum number of deviations in the quality of water from bores could be $640: 32$ bores $* 5$ indicators $* 4$ quarters $=640$. The largest number of deviations was in terms of "turbidity" (91 deviations), "color" (70 deviations), "Total iron" (68 deviations), slight deviations in odor (31 deviations) and singly ammonium nitrogen (4 deviations) in the IV quarter in the bores of pig farms No. 3-5.

The sampling and research of water samples from surface water bodies and wells near pig farms No. 11 (Fig. 7) and No. 10 (Fig. 8) was carried out in the third quarter - September 2020.

As can be seen from Fig. 7, the largest deviations from the established were at the surface reservoir on indicators: color -42 degrees ( 2 times), odor at $60{ }^{\circ} \mathrm{C}-4$ points ( 2 times), turbidity - 
$21 \mathrm{mg} / \mathrm{dm}^{3}$ (14 times), hydrogen indicator - 62.4 (9 times). In the water samples, taken from the wells, no excess was detected.

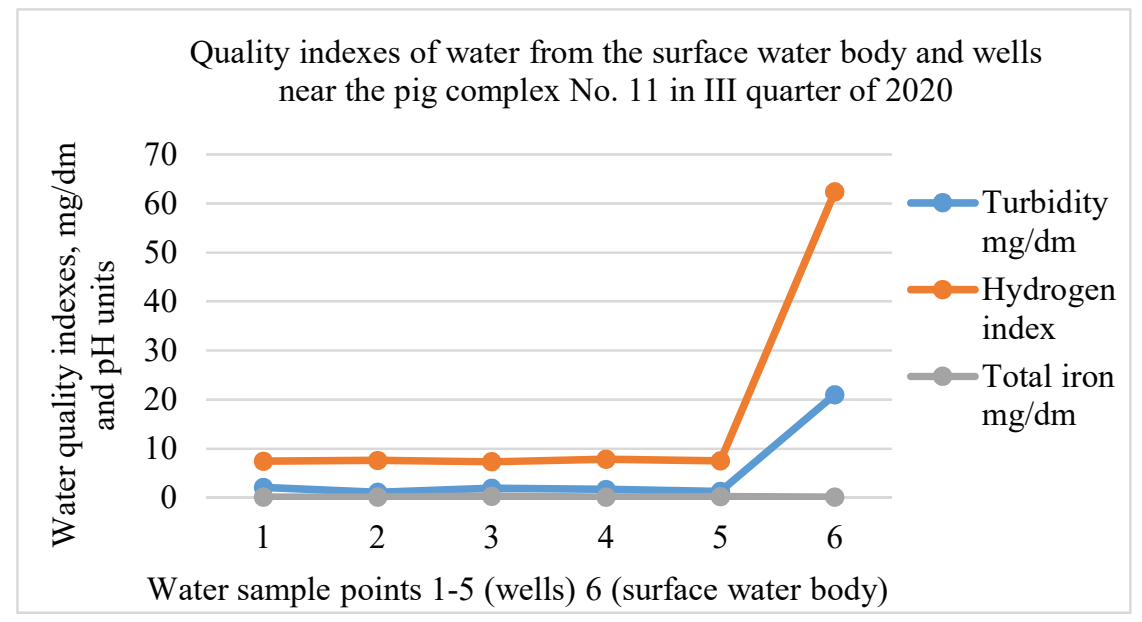

Fig. 7. Water quality from the surface water body and wells near the pig complex No. 11 in the III quarter of 2020

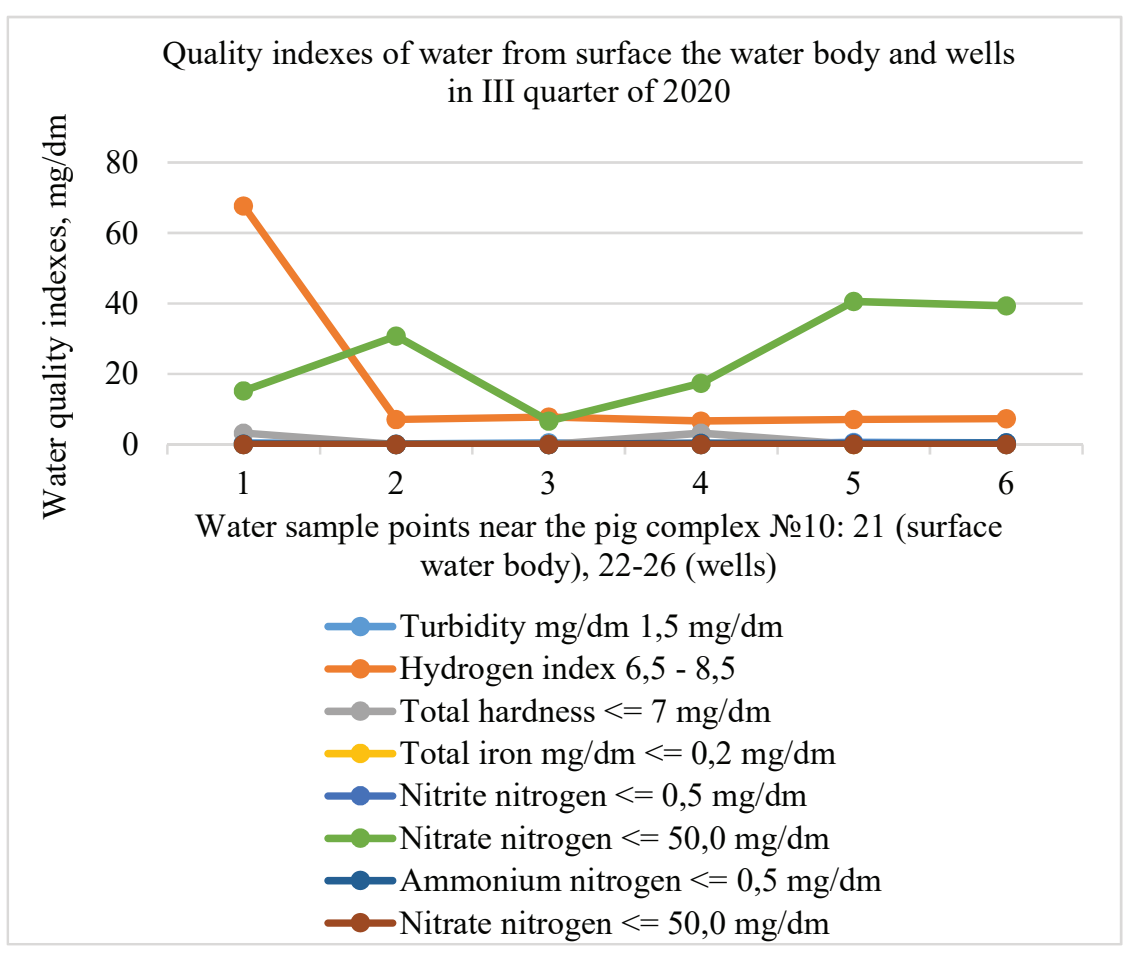

Fig. 8. Water quality from the surface water body and wells near the pig complex No. 10 in the III quarter of 2020

As can be seen from Fig. 8, the highest deviations from the established were at the surface reservoir on indicators: color -260 degrees (13 times), odor at $60{ }^{\circ} \mathrm{C}-5$ points $(2.5$ times), hydrogen indicator -67.7 ( 9 times) and total iron $-0.435 \mathrm{mg} / \mathrm{dm}^{3}$ (2 times). In the water samples, taken from the wells, the excess showed almost 2 times the total hardness and total iron $-14 \mathrm{mg} / \mathrm{dm}^{3}$ and $0.440 \mathrm{mg} / \mathrm{dm}^{3}$, respectively.

The obtained data of the first year of water research allowed to determine the seasonal dynamics of changes in water quality in the bores. During the research, background indicators were 
established in the surface reservoirs and the wells, located near the complexes No. 10 and No. 11. Since there are no background concentrations, the obtained data will be taken as background in further studies in 2021-2026. Further research will establish the impact of the enterprise on water resources.

The research was conducted on the monitoring network according to the developed and approved monitoring plan for the AE LLC "Niva of Pereyaslavshchyna", which the company has the opportunity to be guided in its work. The plan defines the points of the monitoring network, frequency, indicators and methods of research, according to the State sanitary norms and rules "Hygienic requirements for drinking water intended for human consumption" (SSanRN 2.2.4-171-10) [15]. The water samples were examined on the day of sampling, not preserved. The water temperature was important, as laboratory control of samples is carried out from $+5{ }^{\circ} \mathrm{C}$ to $+20^{\circ} \mathrm{C}$.

Further research of waters and control over their quality will provide an opportunity to determine the impact of the complex on the water horizon. The information, obtained as a result of monitoring studies, will allow the rational management of water resources, to anticipate and prevent undesirable situations, related to changes in water quality and determine the reserves of groundwater of drinking quality.

\section{Conclusions} we found:

After conducting the study of water from bores, wells and surface water bodies during 2020,

- the quality of water from bores during the year has not changed significantly;

- no deviations on specific indicators, such as nitrates, nitrites, microbiological contamination;

- it was found, that the deviation in ammonium nitrogen (4 deviations) in the IV quarter at pig complexes No. 3-5 occurred in reserve bores, which was caused by a decrease in production and stagnation of water in the pipes, the highest excess was $4.9 \mathrm{mg} / \mathrm{dm}^{3}$ (in 1.9 times) in the borel No. 8 , complex No. 4;

- the exceeded indicators of water samples from bores, related to the geological features of the research area (aquifer of Eocene sediments): turbidity (91 deviations), color (70 deviations), total iron (68 deviations). During the year, 128 water samples were tested (32 samples quarterly);

- the flow rate of the bores remained constant and corresponded to the passport data (static and dynamic levels did not change);

- in the I, III and IV quarters the quality of water from the bores belonged to the classification of deviations «average deviations», in the II quarter - moderate deviations.

- the quality of construction and sealing of bores and liquid collectors is made technically correct, which prevents the ingress of effluents from manure or pesticides and agrochemicals from fields into groundwater or surface water;

- the studied water samples from the surface reservoirs and the wells near the pig complexes No. 10 and No. 11 indicate qualitative deviations from the standard, respectively $18 \%$ and $11 \%$ of the total number of samples taken. Deviations are "moderate", as they are in the range of $1-30 \%$ of the maximum $100 \%$ and for further research will be taken as background.

- the hydrogen index in the pond and the river showed an excess of 9 times, which indicates anthropogenic pollution, carried out before the implementation of the planned activities of the AE LLC "Niva of Pereyaslavshchyna", i.e. construction of complexes No. 10 (end of 2019) and No. 11 (beginning of 2020);

- the score "highest deviations" in the selected samples was not exceeded in any quarter.

The term "water pollution indicators" was not used in the research, as water pollution is caused by anthropogenic activity, which directly or indirectly affects the change of chemical indicators and, in case of excessive water use, the flow rate of bores.

The studies of the impact of the groundwater aquifer on the qualitative and quantitative characteristics, conducted during the first year on the established monitoring network, did not show a significant impact of AE LLC "Niva of Pereyaslavshchyna" on groundwater resources. Further research in 2021-2026 will allow to establish the seasonal impact of the complex on the water resources of the region and to determine the degree of this impact for further rational use of water resources. 


\section{References}

[1] Chowdhury, S. (2013). Exposure assessment for trihalomethanes in municipal drinking water and risk reduction strategy. Science of The Total Environment, 463-464, 922-930. doi: https://doi.org/10.1016/j.scitotenv.2013.06.104

[2] Mohamed, A. K., Dan, L., Kai, S., Eldaw, E., Abualela, S. (2019). Evaluating the suitability of groundwater for drinking purposes in the North Chengdu Plain, China. E3S Web of Conferences, 81, 01006. doi: https://doi.org/10.1051/e3sconf/20198101006

[3] Adimalla, N., Vasa, S. K., Li, P. (2018). Evaluation of groundwater quality, Peddavagu in Central Telangana (PCT), South India: an insight of controlling factors of fluoride enrichment. Modeling Earth Systems and Environment, 4 (2), 841-852. doi: https://doi.org/10.1007/s40808-018-0443-z

[4] Ndoye, S., Fontaine, C., Gaye, C., Razack, M. (2018). Groundwater Quality and Suitability for Different Uses in the Saloum Area of Senegal. Water, 10 (12), 1837. doi: https://doi.org/10.3390/w10121837

[5] Zakharenko, M. O., Yaremchuk, O. S., Shevchenko, L. V., Poliakovskyi, V. M., Mykhalska, V. M., Maliuha, L. V., Kovalenko, V. O. (2015). Biotekhnolohiya vidkhodiv tvarynnytskykh pidpryiemstv. Kyiv, 380. Available at: http://repository.vsau.org/ getfile.php/19557.pdf

[6] Sahoo, P. K., Kim, K., Powell, M. A. (2016). Managing Groundwater Nitrate Contamination from Livestock Farms: Implication for Nitrate Management Guidelines. Current Pollution Reports, 2 (3), 178-187. doi: https://doi.org/10.1007/s40726-016-0033-5

[7] Mirzaie-Nodoushan, F., Bozorg-Haddad, O., Loáiciga, H. A. (2017). Optimal design of groundwater-level monitoring networks. Journal of Hydroinformatics, 19 (6), 920-929. doi: https://doi.org/10.2166/hydro.2017.044

[8] Lee, G.-M., Park, S., Kim, K.-I., Jeon, S.-H., Song, D., Kim, D. et. al. (2017). Evaluation for Impacts of Nitrogen Source to Groundwater Quality in Livestock Farming Area. Korean Journal of Soil Science and Fertilizer, 50 (5), 345-356. doi: https:// doi.org/10.7745/KJSSF.2017.50.5.345

[9] Kavusi, M., Khashei Siuki, A., Dastourani, M. (2020). Optimal Design of Groundwater Monitoring Network Using the Combined Election-Kriging Method. Water Resources Management, 34 (8), 2503-2516. doi: https://doi.org/10.1007/s11269-020-02568-7

[10] Sasakova, N., Veselitz-Lakticova, K., Hromada, R., Chvojka, D., Kosco, J., Ondrasovic, M. (2013). Contamination of Individual sources of drinking water located in environmentally polluted central spis region (Slovakia). Journal of Microbiology, Biotechnology and Food Sciences, 3 (3), 262-265. Available at: https://www.jmbfs.org/jmbfs_sasakova_godole/?issue_id=2830\&article_id=18

[11] Fridrich, B., Krčmar, D., Dalmacija, B., Molnar, J., Pešić, V., Kragulj, M., Varga, N. (2014). Impact of wastewater from pig farm lagoons on the quality of local groundwater. Agricultural Water Management, 135, 40-53. doi: https://doi.org/10.1016/ j.agwat.2013.12.014

[12] Sasakova, N., Gregova, G., Takacova, D., Mojzisova, J., Papajova, I., Venglovsky, J. et. al. (2018). Pollution of Surface and Ground Water by Sources Related to Agricultural Activities. Frontiers in Sustainable Food Systems, 2. doi: https://doi.org/10.3389/ fsufs.2018.00042

[13] Hidroheolohichna karta Ukrainy. Karty Ukrainy. Available at: https://geomap.land.kiev.ua/water.html

[14] Doreau, M., Corson, M. S., Wiedemann, S. G. (2012). Water use by livestock: A global perspective for a regional issue? Animal Frontiers, 2 (2), 9-16. doi: https://doi.org/10.2527/af.2012-0036

[15] Pro zatverdzhennia Derzhavnykh sanitarnykh norm ta pravyl "Hihienichni vymohy do vody pytnoi, pryznachenoi dlia spozhyvannia liudynoiu” (DSanPiN 2.2.4-171-10). Verkhovna Rada of Ukraine. Available at: https://zakon.rada.gov.ua/laws/ show/z0452-10\#Text

[16] GOST 3351-74. Drinking water. Methods for determination of odour, taste, colour and turbidity (1974). Moscow: Mezhgosudarstvenniy standart. Available at: https://files.stroyinf.ru/Data/363/36376.pdf

[17] DSTU 4077-2001. Yakist vody. Vyznachennia rN (2001). Kyiv: Ukraina: Derzhavnyi Standart Ukrainy. Available at: http:// online.budstandart.com/ru/catalog/doc-page?id_doc $=52791$

[18] DSTU ISO 11885:2005. Yakist vody. Vyznachannia 33 elementiv metodom atomno-emisiynoi spektrometriyi z induktyvnozv'yazanoiu plazmoiu (ISO 11885:1996, IDT) (2005). Kyiv: Derzhavnyi Standart Ukrainy. Available at: https://budstandart.ua/normativ-document.html?id_doc $=51733 \&$ minregion $=852$

[19] GOST 18309-72. Voda pit'evaya. Metod opredeleniya soderzhaniya polifosfatov (1972). Moscow: Mezhgosudarstvenniy standart. Available at: http://vsegost.com/Catalog/17/17680.shtml

[20] GOST 4389-72. Drinking water. Method for determination of sulphate content (1972). Moscow: Mezhgosudarstvenniy standart. Available at: http://online.budstandart.com/ru/catalog/doc-page?id_doc=48298

[21] GOST 4245-72. Drinking water. Methods for determination of chloride content (1972). Moscow: Mezhgosudarstvenniy standart. Available at: https://docs.cntd.ru/document/1200008214

[22] GOST 4192-82. Drinking water. Methods of determination of mineral nitrogen-containing matters (1982). Moscow: Gosudarstvenniy Standart Soyuza SSR. Available at: http:/www.opengost.ru/iso/3969-gost-4192-82-voda-pitevaya.-metody-opredeleniya-mineralnyh-azotsoderzhaschih-veschestv.html 
[23] GOST 18826-73. Drinking Water. Methods for determination of Nitrates Content. Available at: http://www.vashdom.ru/ gost $/ 18826-73$

[24] GOST 4011-72. Drinking water. Methods for determination of total iron. Available at: https://docs.cntd.ru/document/1200008210

[25] GOST 4151-72. Drinking water. Method for determination of total hardness content. Available at: https://znaytovar.ru/gost/2/ GOST 415172 Voda_pitevaya_Meto.html

[26] Pro zatverdzhennia metodychnykh vkazivok "Sanitarno-mikrobiolohichnyi kontrol yakosti pytnoi vody". Verkhovna Rada of Ukraine. Available at: https://zakon.rada.gov.ua/rada/show/v0060282-05\#Text

[27] Pro zatverdzhennia metodychnykh rekomendatsiyi "Vyznachennia naibilsh virohidnoho chysla mikroorhanizmiv u vodi z vykorystanniam testiv diahnostychnykh Quanti-Disc ta SimPlate". Verkhovna Rada of Ukraine. Available at: https://zakon. rada.gov.ua/rada/show/v0138282-08\#Text

[28] Metodychni vkazivky po sanitarno-mikrobiolohichnomu analizu vody poverkhnevykh vodoim. Available at: http://online. budstandart.com/ua/catalog/doc-page.html?id_doc $=72438$

Received date 01.06.2021

Accepted date 04.08.2021

Published date 15.09.2021
(C) The Author(s) 2021

This is an open access article under the Creative Commons CC BY license

How to cite: Serdiuk, V., Maksin, V. (2021). Creation of an observation network for assessment of the impact of the pig complex on the groundwater aquifer. EUREKA: Life Sciences, 5, 35-45. doi: https://doi.org/10.21303/2504-5695.2021.002062 